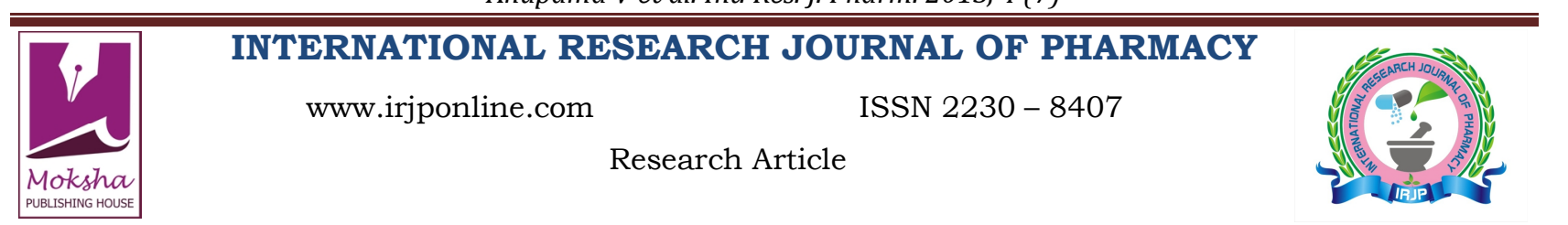

\title{
OPTIMIZATION, ISOLATION AND PARTIAL CHARACTERIZATION OF PROTEASES FROM UNDERUTILIZED AND COMMON FOOD LEGUMES
}

Anupama V., Marimuthu M., Uma Sundaram, Gurumoorthi P*

Nutracuetical Lab, Department of Food Process Engineering, School of Bioengineering, SRM University, Kattankulathur, Tamil Nadu, India

*Corresponding Author Email: p_gurumoorthi@yahoo.com

Article Received on: 18/03/13 Revised on: 09/04/13 Approved for publication: 10/05/13

DOI: $10.7897 / 2230-8407.04722$

IRJP is an official publication of Moksha Publishing House. Website: www.mokshaph.com

(C) All rights reserved.

\section{ABSTRACT}

The present study aims at the isolation and partial characterization of proteases from six legume seeds, horse gram, jack bean, lima bean and velvet bean (white and black seeds). The extraction of these seeds was optimized using response surface methodology. The best buffer for extraction was seen to be 10 $\mathrm{mM}$ Tris $\mathrm{HCl}$ at $\mathrm{pH} 8$ with $25 \mathrm{mg} / \mathrm{ml}-45 \mathrm{mg} / \mathrm{ml}$ protein release. The ideal extraction parameters exhibiting highest protease release (91.9112 $\mathrm{U}) \mathrm{were}$ pH 4.86 , $10-15^{\circ} \mathrm{C}$ with 70 hours incubation time. The optimized extracts were subjected to $\left(\mathrm{NH}_{4}\right)_{2} \mathrm{SO}_{4}$ precipitation to obtain crude enzyme solution. The proteolytic activity of the precipitated enzyme was again checked. The effect of $\mathrm{pH}$ and temperature of protease activity in the crude enzyme solution were also determined. The $\mathrm{pH}$ profile of proteases showed proteolytic activity at $\mathrm{pH} 7.5$ to 9.0. The paper concludes that leguminous seeds can be source of proteases for industrial purposes.

Keywords: Macrotyloma uniflorum, Phaseolus lunatus, Canavalia ensiformis, Mucuna pruriens, Protease.

\section{INTRODUCTION}

Proteases, a group of hydrolytic enzymes are mostly sourced from microorganisms and the fermentation processes they are involved in. Ashton, F. ${ }^{1}$ and Ichishima ${ }^{2}$ reported proteases which are widely distributed in plants, especially leguminous seeds and found that such proteases were mainly alkaline or neutral in nature with optimal $\mathrm{pH}$ of about 2-3. The activity of proteases in green gram has been studied and reported during germination ${ }^{3,4}$. Such proteases play a very important role in the physiology of seed proteins, such as the formation of enzymes that eliminate or reduce the anti nutritional and indigestible components of leguminous seeds during germination ${ }^{5}$. Apart from this, such proteases if isolated may benefit many an industrial process. The protease enzymes are currently used to a great extent in the pharmaceutical, leather and various foods processing industries ${ }^{6}$. Dry legumes are an excellent source of protein, energy and other nutrients in developing countries and also contain varied amounts phytochemical compounds including antioxidants ${ }^{7}$. However their use is limited due to their high dietary bulk; presence of anti nutritional factors, mainly phytic acid in most of the legumes; low protein and carbohydrate digestibility ${ }^{8-11}$. During germination of seeds, $\alpha$-amylase and protease, that are developed, degrade starch granules and reserve proteins, respectively; thereby reducing the dietary bulk and improving the digestibility of starch and protein ${ }^{12-14}$. Germination was also shown to increase the monosaccharide and decrease the disaccharide contents of legumes due to $\alpha$-amylase ${ }^{15}$. Hence, enhanced amylase and protease activities in germinated legumes may improve the nutritional quality, which makes them important in improvement of nutritive value of leguminous seeds. The malting capacity and enzymatic changes of different cereals have been studied in great deal with regard to their use, especially the amylases in germinating cereals in several cereal species ${ }^{16,17}$. But a comprehensive data on key enzymes (phytase, $\alpha$-amylase and protease) in legume seeds is scarce, so the present was planned with an objective to obtain more information on enzymatic activities in legume seeds. Thus, in this context the current study aims at the isolation and partial characterization of a novel protease from underutilized tribal legumes, with a view of better utilization and commercialization of these as an alternative source of proteolytic enzymes.

\section{MATERIALS AND METHODS}

\section{Material Collection}

Natural strands of mature pods of Macrotyloma uniflorum (horse gram), Phaseolus lunatus (lima bean) and Canavalia ensiformis (jack bean) were purchased from local markets of Madurai, Tamil Nadu, India. Mucuna pruriens (L.) DC (velvet bean) black and white coat seeds were collected as mature pods from the different agro-climatic regions of Western Ghats, Tamil Nadu, India. After drying in the sun, the pods were thrashed to separate mature seeds. After thorough cleaning and removal of broken seeds and foreign materials, the seeds were stored in plastic containers at room temperature $\left(25^{\circ} \mathrm{C}\right)$ until further use.

\section{Isolation and preparation of crude protease enzyme}

The initial step in the extraction process was germination of the seeds. The seeds were sterilized with $0.1 \%$ mercuric chloride and washed, were soaked in distilled water at $4^{\circ} \mathrm{C}$ for $12 \mathrm{~h}$. The soaked seeds were allowed to germinate for 24 , $48,72,96$ and $120 \mathrm{~h}$ at $30^{\circ} \mathrm{C}$. The seeds were moistened with distilled water at regular intervals of $12 \mathrm{~h}$. The sprouts were rinsed with distilled water and freeze- $\operatorname{dried}^{18}$. The germinated freeze dried seeds were then ground in a Wiley Mill (Scientific Equipment Works, New Delhi, India) to 60mesh size with acetone to eliminate fat content. The mixture thus obtained was filtered through double layer Whatmann No.1 filter papers. The homogenates were dried in a tray drier overnight at $32{ }^{\circ} \mathrm{C}$. The dry homogenate, was further coarsely ground using mortar and pestle at $1-2{ }^{0} \mathrm{C}$ and the powder obtained was suspended in three kinds of buffer solutions and the efficacy of each buffer was estimated by checking the protein release in each after an incubation of $24 \mathrm{~h}$. The three buffers used were the phosphate buffer $(10 \mathrm{mM} \mathrm{pH} 8)$, Tris $\mathrm{HCl}(10 \mathrm{mM}, \mathrm{pH} 8)$ and deionized water. The extracts 
obtained were tested for protein content using method of Bradford $^{19}$. From these, the buffer that showed maximum protease release was used in further processing. The mixture of the optimized buffer, homogenate powder was spiked with $2 \mathrm{M} \mathrm{NaCl}$ and incubated for $24 \mathrm{~h}$ at room temperature. This mixture was further filtered and centrifuged at $10000 \mathrm{rpm}$ for 8 minutes below $4^{\circ} \mathrm{C}$ in a KUBOTA 6500 high speed refrigerated centrifuge. The supernatant was collected and further processed ${ }^{20,21}$.

\section{Optimization of Extraction Parameters}

A full factorial design including all possible factor combinations in each factor is a powerful tool in understanding complex processes and to describe factor interactions in multifactor systems. Response Surface Methodology is an empirical statistical technique employed for multiple regression analysis by using quantitative data obtained from properly designed experiments to solve multivariate equations simultaneously ${ }^{22}$. The powder homogenate was suspended in $10 \mathrm{mM}$ Tris $\mathrm{HCl}$ buffer with variations in $\mathrm{pH}$, time of incubation and temperature of incubation.

The coded values of the process parameters were determined by the following equation.

$$
x_{t}=\frac{x_{t}-x_{0}}{\Delta x}
$$

Where xi-coded value of the $i^{\text {th }}$ variable, Xi-uncoded value of the $i^{\text {th }}$ test variable and $\mathrm{X}_{0}$-uncoded value of the $\mathrm{i}^{\text {th }}$ test variable at center point.

The range and levels of individual variables are given in Table 1. The experimental design is given in Table 2, along with experimental data and predicted responses. The regression analysis was performed to estimate the response function as a second order polynomial.

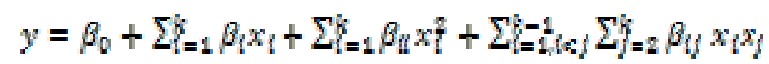

(2)

Where $Y$ is the predicted response, $\beta \mathrm{i}, \beta \mathrm{j}, \beta \mathrm{ij}$ are coefficients estimated from regression. They represent the linear, quadratic and cross products of $\mathrm{X}_{1}, \mathrm{X}_{2}$, and $\mathrm{X}_{3}$ on response.

A statistical program package Design Expert 8.0.7.1, was used for regression analysis of the data obtained and to estimate the coefficient of the regression equation. The equations were validated by the statistical tests called the ANOVA analysis. The significance of each term in the Equation is to estimate the goodness of fit in each case. Response surfaces were drawn to determine the individual and interactive effects of the test variable on the protease production.

\section{Ammonium Sulphate precipitation}

The optimized extracts were saturated with $50 \%$ solid $\left(\mathrm{NH}_{4}\right)_{2} \mathrm{SO}_{4}$ for overnight precipitation. After precipitation, they were centrifuged at $10000 \mathrm{rpm}$ for $30 \mathrm{~min}$ below $4{ }^{0} \mathrm{C}^{23}$. The amount of salt required for effective precipitation was calculated by the Ammonium Sulphate Calculator from EnCor Biotechnology Pvt. Limited, Florida. The collected precipitated were dissolved in $10 \mathrm{mM}$ Tris- $\mathrm{HCl}$ buffer $(\mathrm{pH} 8)$ and centrifuged at $5000 \mathrm{rpm}$ for $10 \mathrm{~min}$. The supernatant was used as crude enzyme for the assay of specific activity of enzyme and characterization.

\section{Water Soluble Protein measurement}

Protein concentration was determined method described by Lowry ${ }^{24}$, using bovine serum albumin (BSA) as standard protein. The amount of the soluble protein was calculated from the standard curve as $\mathrm{mg}$ of protein per $\mathrm{ml}$ of test samples.

\section{Protease Activity Estimation}

Protease activity in the optimized extracts was assayed using the method of Kuntz ${ }^{25}$ using casein as a substrate. In this, a $1 \%(\mathrm{w} / \mathrm{v})$ solution of casein was prepared in $0.5 \mathrm{M}$ Carbonate Buffer, $\mathrm{pH} 9.5$ to this; $1 \mathrm{ml}$ of suitably diluted extract was added and incubated at $37{ }^{\circ} \mathrm{C}$ for $10 \mathrm{~min}$. The reaction post incubation was terminated by adding 5\% TCA solution and the mixture was incubated at room temperature for 10 minutes. The precipitate was filtered using Whatmann No. 1 filter paper and the absorbance of the filtrate was read at 280 nm using a CECIL CE-7200 UV-Visible Spectrophotometer. A standard curve of tyrosine activity upon casein was prepared and used to estimate the protease activity of the extracts. The enzyme is assayed in terms of its activity and the activity is expressed in "units".

$$
1 \mathrm{U}=1 \mathrm{mg} / 10 \mathrm{~min}
$$

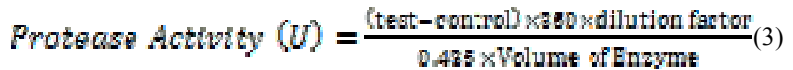

Effect of $\mathrm{pH}$ and temperature specific activity of proteases: Partial characterization

Optimum temperature and $\mathrm{pH}$ of protease activity were determined using various temperatures $\left(10{ }^{\circ} \mathrm{C}, 37{ }^{\circ} \mathrm{C}\right.$ and 70 $\left.{ }^{0} \mathrm{C}\right)$ and $\mathrm{pH}(2,7$ and 14). This was done to establish the stability and to partially characterize the crude enzyme ${ }^{26}$.

\section{RESULTS AND DISCUSSION Optimization and Selection of Buffer}

Two buffers and de-ionized water were used to extract the homogenate powders in this study. The extraction was carried out in a ration of 10:1 of buffer and powder respectively. The Bradford's assay was used to determine the protein released in each solution after incubation of $24 \mathrm{~h}$ at room temperature. The results are as seen in Figure 1. The highest protein release was seen in $10 \mathrm{mM}$ Tris $\mathrm{HCl}$ at $\mathrm{pH} 8(25 \mathrm{mg} / \mathrm{ml}-45$ $\mathrm{mg} / \mathrm{ml}$ ) and thus, this was used in the further studies carried out.

\section{Optimization of Extraction Parameters}

To examine the combined effect of the different process parameters (independent variables), on the release of protease, a Box Benkhen design with 5 center points in Quadratic design mode was used. A total of 17 trials were performed according to the design generated. The extraction of horse gram, lima bean, jack bean and velvet bean (black and white) was carried out with reference to the mathematical model relating the protease production to the parameters using 2 factor interaction manual models. The equations for the same were as seen below. 


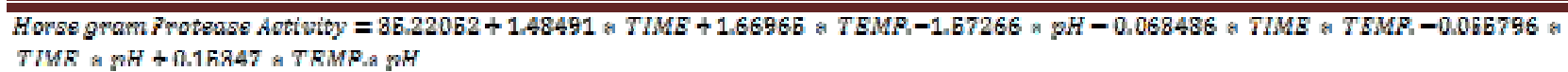

(5)

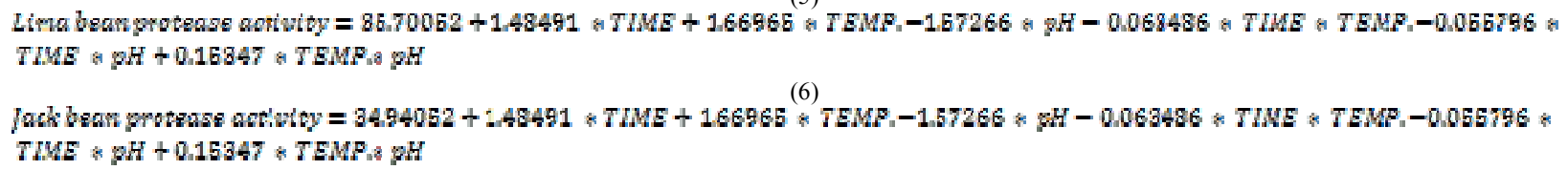

(6)

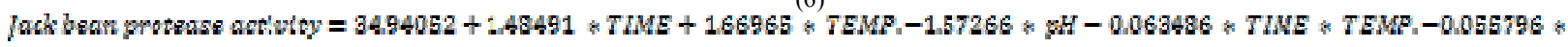
$T H E * p H+0.15947+T E M P * F H$

(7)

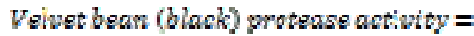

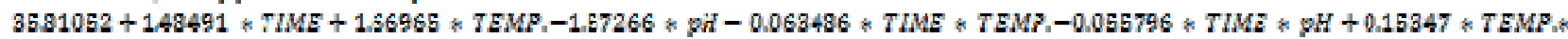
\%म

Veinet bean (White) (wotease antwity $=$

(8)

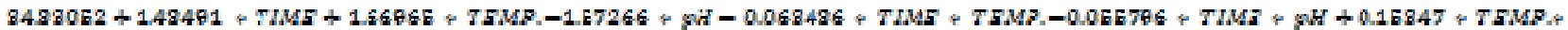
$\%$

(9)

The Analysis of Variance for the above defined model in 2 factor interaction mode was performed and the results were as indicated in Table 3. According to the ANOVA results, the models for all five responses were significant. The Model Fvalue of 4.27 implied the model to be significant with only a $2.16 \%$ chance of such a value occurring due to noise. Model F-value was calculated as a ratio of mean square regression and mean square residual. The $\mathrm{p}$ value at 0.0216 lays further emphasis on the significance of the model. The most significant model terms in the current design were seen to be $\mathrm{AB}$ wherein $\mathrm{A}$ is the time of extraction, $\mathrm{B}$ the temperature and $\mathrm{C}$ the $\mathrm{pH}$ of extraction media. The predicted $\mathrm{R}^{2}$ of 0.3340 is in practical agreement with the adjusted $R^{2}$ of 0.5505 . Adequate precision is the ratio that measures the signal to noise ratio. A ratio greater than 4 is generally considered to be most desirable. The adequate precision ratio of the experimental model at 7.414 indicates an adequate signal and that this model can be used to navigate the design space adequately. The fit of the model was also expressed by the coefficient of regression $\mathrm{R}^{2}$, which was found to be 0.7191 indicating that almost $72 \%$ of the variability in the response could be explained by the model. This implies that the prediction of experimental data is quite satisfactory. To investigate the interactive effect of the factors on the release of protease, three-dimensional plots were drawn. Figure 2 represents the contour plot of the experimental model. Figure $2 \mathrm{a}$ shows the contour plot of the influence of time and temperature on the activity of protease in the extracts. The analysis for the generation of this response was performed, considering $\mathrm{pH}$ as a slice in the factorial of time vs. temperature space. From this graph, it was concluded that at higher limit of time and middle level of temperature (72 h, $\left.10-20^{\circ} \mathrm{C}\right)$ the release of protease was heightened. As indicated from Figure $2 b$, a response with temperature as the variable factor or a slice in the time vs. $\mathrm{pH}$ space, the protease release is highest at higher time, temperature values and $\mathrm{pH}$ up to 7.4. Figure $2 \mathrm{c}$ shows the interaction of the protease release with respect to $\mathrm{pH}$ and temperature with time as the variable factor. From this graph, it is evident that a higher value of time increases the release of protease along with temperatures within $20^{\circ} \mathrm{C}$ and $\mathrm{pH}$ up to 7.4 as seen before also. In order to further emphasize the results seen in the contour plots, the 3D response surface plots were generated. The $3 \mathrm{D}$ response plots are as seen in Figure 3. From Figure 3a, it can be deduced that the information from the contour plots is further emphasized. The plot had $\mathrm{pH}$ as variable factor and the best response was obtained at a $\mathrm{pH}$ of about 4.86. From Figure 3b, it can be concluded that the temperature that is most optimal for the release of protease is about $10.19^{\circ} \mathrm{C}$ this is also in relative agreement with the contour plot. In Figure $3 \mathrm{c}$, the indication is of ideal time for maximum protease release. This is observed at about $70 \mathrm{~h}$ which again lays emphasis on the results observed in the corresponding contour plot. Thus, with the agreement between the contour and 3D surface plots, we can identify the ideal points of highest protease release $(91.9112 \mathrm{U})$ at $4.86 \mathrm{pH}, 10-15^{\circ} \mathrm{C}$ and $70 \mathrm{~h}$ incubation time.

\section{Ammonium Sulphate Precipitation}

The amount of solid ammonium sulphate added to obtain a $50 \%$ saturated solution was $15.26 \mathrm{~g} / 50 \mathrm{ml}$ of extract. The precipitation was carried out at $10^{\circ} \mathrm{C}$ and was incubated overnight, followed by the washing of the precipitate. The precipitate after washing was dissolved in $10 \mathrm{mM}$ Tris-HCl buffer $(\mathrm{pH} 8)$ and then centrifuged again. The supernatant thus obtained was used as the crude enzyme.

The efficiency of the precipitation, was estimated by checking the protease activity in the extract and crude enzyme. The results (Table 4) of this showed the protease activity in the crude enzyme solution to be greater than that of the extract by around 0.5 in each seed.

\section{Water Soluble Protein}

The protein content in the crude enzyme solutions were analysed. It was seen that almost all the seeds showed a high concentration of proteins. Among the seeds under study here, horse gram was found to have highest protein content at 224 $\mathrm{mg} / \mathrm{ml}$. The results were as indicated in Figure 4.

\section{Protease Activity Estimation}

The amount of protease was measred and estimated using tyrosine as the standard. After the calculations as per eq. 3 were done, the results obtained were represented as a bar graph as shown in Figure 5. The highest protease release was observed in Jack bean (92.39 U).

\section{Effect of $\mathrm{pH}$ and temperature on protease activity}

The sensitivity of the crude enzyme solution, was tested to ascertain the stability of the crude enzyme isolate. The enzyme solution exhibited maximum stability at $\mathrm{pH} 2$ and 7 when compared to $\mathrm{pH} 14$ (Table 5). The enzyme solution was also stable at $37^{\circ} \mathrm{C}$ but started to show a marked reduction in activity at temeratures above $37^{\circ} \mathrm{C}$ (Table 6). A very similar result ( $\mathrm{pH}$ stability at 8.4 and 9.2) was also reported by Evans et al., 2011 for the extract of palm weevil (Rhynchophorous palmarum). The results from effect of $\mathrm{pH}$ indicate that the alkaline proteases involved in all the seeds were more potent than the acidic proteases. This alkaline protease may be playing an important role in industrial food applications such 
Anupama V et al. Int. Res. J. Pharm. 2013, 4 (7)

as production of soy sauce, digestion of soy bean protein and in leather and detergent industries ${ }^{27,28}$. Dahot ${ }^{29}$ investigated on plant protease and found that the optimum temperature for enzyme reaction was $35^{\circ} \mathrm{C}$, which was a good consistent with our results but Evans ${ }^{30}$ reported optimum temperature for the palm weevil was $23^{\circ} \mathrm{C}$ on $0.03 \%$ casein. Kamini ${ }^{31}$ and $\mathrm{Aoki}^{32}$ have shown that the protease activity with optimum temperature less than $20^{\circ} \mathrm{C}$ is considered as a cold protease. Therefore, the proteases isolated in the present study may be an excellent source of enzymes for industrial purposes that require low or mild temperatures as a vital factor in the processing steps.

Table 1: Extraction Parameters and limits used in design of optimization experiment

\begin{tabular}{|c|c|}
\hline Parameter & Levels \\
\hline $\mathrm{pH}$ & $3.0-14.0$ \\
\hline Time & $24-72$ \\
\hline Temperature & $10.0-30.0$ \\
\hline
\end{tabular}

Table 2: Designed experiment with actual and predicted values

\begin{tabular}{|c|c|c|c|c|c|c|c|c|c|c|c|c|c|}
\hline \multirow[t]{3}{*}{ Run } & \multirow{3}{*}{$\begin{array}{c}\text { Time } \\
\text { (hour) }\end{array}$} & \multirow{3}{*}{$\begin{array}{c}\text { Temp. } \\
\text { ( C) }\end{array}$} & \multirow[t]{3}{*}{ pH } & \multicolumn{9}{|c|}{ Protease Activity (U) * } & \\
\hline & & & & \multicolumn{2}{|c|}{ Horse Gram } & \multicolumn{2}{|c|}{ Lima Bean } & \multicolumn{2}{|c|}{ Jack Bean } & \multicolumn{2}{|c|}{$\begin{array}{c}\text { Velvet Bean } \\
\text { (White) }\end{array}$} & \multicolumn{2}{|c|}{$\begin{array}{c}\text { Velvet Bean } \\
\text { (Black) }\end{array}$} \\
\hline & & & & Actual & Predicted & Actual & Predicted & Actual & Predicted & Actual & Predicted & Actual & Predicted \\
\hline 1 & 72 & 30 & 8.5 & 41.847 & 46.7138 & 42.327 & 47.193 & 41.567 & 46.433 & 42.437 & 47.3038 & 41.457 & 46.3238 \\
\hline 2 & 72 & 20 & 14 & 50.128 & 48.8189 & 50.608 & 49.298 & 49.848 & 48.538 & 50.718 & 49.4089 & 49.738 & 48.4289 \\
\hline 3 & 48 & 10 & 14 & 46.403 & 54.6928 & 46.883 & 55.172 & 46.123 & 54.412 & 46.993 & 55.2828 & 46.013 & 54.3028 \\
\hline 4 & 24 & 10 & 8.5 & 57.019 & 60.613 & 57.499 & 61.093 & 56.739 & 60.333 & 57.609 & 61.203 & 56.629 & 60.223 \\
\hline 5 & 48 & 30 & 3 & 67.483 & 66.2256 & 67.963 & 66.705 & 67.203 & 65.945 & 68.073 & 66.8156 & 67.093 & 65.8356 \\
\hline 6 & 48 & 30 & 14 & 67.139 & 70.1108 & 67.619 & 70.590 & 66.859 & 69.830 & 67.729 & 70.7008 & 66.749 & 69.7208 \\
\hline 7 & 48 & 20 & 8.5 & 74.764 & 68.9 & 75.244 & 69.38 & 74.484 & 68.62 & 75.354 & 69.49 & 74.374 & 68.51 \\
\hline 8 & 48 & 20 & 8.5 & 76.754 & 68.9 & 77.234 & 69.38 & 76.474 & 68.62 & 77.344 & 69.49 & 76.364 & 68.51 \\
\hline 9 & 24 & 20 & 3 & 75.375 & 74.251 & 75.855 & 74.731 & 75.095 & 73.971 & 75.965 & 74.841 & 74.985 & 73.861 \\
\hline 10 & 48 & 10 & 3 & 80.511 & 84.5709 & 80.991 & 85.050 & 80.231 & 84.290 & 81.101 & 85.1609 & 80.125 & 84.1809 \\
\hline 11 & 72 & 20 & 3 & 73.625 & 76.5455 & 74.105 & 77.025 & 73.345 & 76.265 & 74.215 & 77.1355 & 73.235 & 76.1555 \\
\hline 12 & 24 & 30 & 8.5 & 80.711 & 89.6227 & 81.191 & 90.102 & 80.431 & 89.342 & 81.301 & 90.2127 & 80.321 & 89.2327 \\
\hline 13 & 48 & 20 & 8.5 & 56.415 & 68.9 & 56.895 & 69.38 & 56.135 & 68.62 & 57.005 & 69.49 & 56.025 & 68.51 \\
\hline 14 & 72 & 10 & 8.5 & 79.101 & 78.6506 & 79.581 & 79.130 & 78.821 & 78.370 & 79.691 & 79.2406 & 78.711 & 78.2606 \\
\hline 15 & 24 & 20 & 14 & 81.339 & 75.9847 & 81.819 & 76.464 & 81.059 & 75.704 & 81.929 & 76.5747 & 80.949 & 75.5947 \\
\hline 16 & 48 & 20 & 8.5 & 81.339 & 68.9 & 81.819 & 69.38 & 81.059 & 68.62 & 81.929 & 69.49 & 80.949 & 68.51 \\
\hline 17 & 48 & 20 & 8.5 & 81.339 & 68.9 & 81.819 & 69.38 & 81.059 & 68.62 & 81.929 & 69.49 & 80.949 & 68.51 \\
\hline
\end{tabular}

$* 1 \mathrm{U}=1 \mathrm{mg} / 10 \mathrm{~min}$.

Table 3: ANOVA of experimental design in 2 FI model

\begin{tabular}{|c|c|c|c|c|c|c|}
\hline Source & $\begin{array}{c}\text { Sum of } \\
\text { Squares }\end{array}$ & Df & Mean Square & F Value & p-value Prob $>$ F & Comments \\
\hline Model & 2081.98 & 6 & 346.996 & 4.26609 & 0.0216 & significant \\
\hline A-TIME & 309.291 & 1 & 309.291 & 3.80253 & 0.0797 & \\
\hline B-TEMP. & 4.28409 & 1 & 4.28409 & 0.05267 & 0.8231 & \\
\hline C-pH & 337.816 & 1 & 337.816 & 4.15323 & 0.0689 & \\
\hline AB & 928.615 & 1 & 928.615 & 11.4167 & 0.007 & \\
\hline AC & 216.979 & 1 & 216.979 & 2.66762 & 0.1335 & \\
\hline BC & 284.99 & 1 & 284.99 & 3.50377 & 0.0907 & \\
\hline Residual & 813.382 & 10 & 81.3382 & & & not significant \\
\hline Lack of Fit & 388.359 & 6 & 64.7264 & 0.60916 & 0.7205 & \\
\hline Pure Error & 425.023 & 4 & 106.256 & & & \\
\hline Cor Total & 2895.36 & 16 & & & & \\
\hline
\end{tabular}

Table 4: Influence of Ammonium Sulphate precipitation on protease activity in extracts

\begin{tabular}{|c|c|c|}
\hline Seed & Extraction/Precipitation & Protease Activity (U) * \\
\hline \multirow{2}{*}{ Horse Gram } & Extract & 93.932 \\
\cline { 2 - 3 } & Precipitate & 94.192 \\
\hline \multirow{2}{*}{ Lima Bean } & Extract & 93 \\
\cline { 2 - 3 } & Precipitate & 93.861 \\
\hline \multirow{2}{*}{ Jack Bean } & Extract & 98.5 \\
\cline { 2 - 3 } & Precipitate & 98.67 \\
\hline \multirow{2}{*}{$\begin{array}{c}\text { Velvet Bean } \\
\text { (Black) }\end{array}$} & Extract & 96 \\
\hline \multirow{2}{*}{$\begin{array}{c}\text { Velvet Bean } \\
\text { (White) }\end{array}$} & Precipitate & 96.8 \\
\cline { 2 - 3 } & Extract & 97 \\
\hline
\end{tabular}

*1 $\mathrm{U}=1 \mathrm{mg} / 10 \mathrm{~min}$. 
Anupama V et al. Int. Res. J. Pharm. 2013, 4 (7)

Table 5: Effect of pH on protease activity in crude extract

\begin{tabular}{|c|c|c|}
\hline $\mathbf{p H}$ & Seed Powder \# & Protease Activity (U) * \\
\hline \multirow{4}{*}{2} & Phaseolus lunatus & 81 \\
\cline { 2 - 3 } & Canavalia ensiformis & 87 \\
\cline { 2 - 3 } & Macrotyloma uniflora & 80 \\
\cline { 2 - 3 } & Mucunna Puriens (White Seed) & 74 \\
\cline { 2 - 3 } & Mucunna Puriens (Black Seed) & 74 \\
\hline 7 & Phaseolus lunatus & 83 \\
\cline { 2 - 3 } & Canavalia ensiformis & 96 \\
\cline { 2 - 3 } & Macrotyloma uniflora & 85 \\
\cline { 2 - 3 } & Mucunna Puriens (White Seed) & 76 \\
\cline { 2 - 3 } & Mucunna Puriens (Black Seed) & 77 \\
\hline 14 & Phaseolus lunatus & 83 \\
\cline { 2 - 3 } & Canavalia ensiformis & 92 \\
\cline { 2 - 3 } & Macrotyloma uniflora & 83 \\
\cline { 2 - 3 } & Mucunna Puriens (White Seed) & 75 \\
\cline { 2 - 3 } & Mucunna Puriens (Black Seed) & 76 \\
\hline
\end{tabular}

\# Macrotyloma uniflorum - horse gram, Phaseolus lunatus - lima bean, Canavalia ensiformis - jack bean, Mucuna pruriens - velvet bean black and white coat seeds, *1 $\mathrm{U}=1 \mathrm{mg} / 10 \mathrm{~min}$.

Table 6: Effect of temperature on protease activity in crude extract

\begin{tabular}{|c|c|c|}
\hline Temperature & Seed Powder \# & Protease Activity $(\mathrm{U})$ * \\
\hline \multirow[t]{5}{*}{10} & Phaseolus lunatus & 79 \\
\hline & Canavalia ensiformis & 85 \\
\hline & Macrotyloma uniflora & 78 \\
\hline & Mucunna Puriens (White Seed) & 72 \\
\hline & Mucunna Puriens (Black Seed) & 72 \\
\hline \multirow[t]{5}{*}{37} & Phaseolus lunatus & 81 \\
\hline & Canavalia ensiformis & 94 \\
\hline & Macrotyloma uniflora & 83 \\
\hline & Mucunna Puriens (White Seed) & 74 \\
\hline & Mucunna Puriens (Black Seed) & 75 \\
\hline \multirow[t]{5}{*}{70} & Phaseolus lunatus & 81 \\
\hline & Canavalia ensiformis & 90 \\
\hline & Macrotyloma uniflora & 81 \\
\hline & Mucunna Puriens (White Seed) & 73 \\
\hline & Mucunna Puriens (Black Seed) & 74 \\
\hline
\end{tabular}

\# Macrotyloma uniflorum - horse gram, Phaseolus lunatus - lima bean, Canavalia ensiformis - jack bean, Mucuna pruriens - velvet bean black and white coat seeds, $* 1 \mathrm{U}=1 \mathrm{mg} / 10 \mathrm{~min}$.

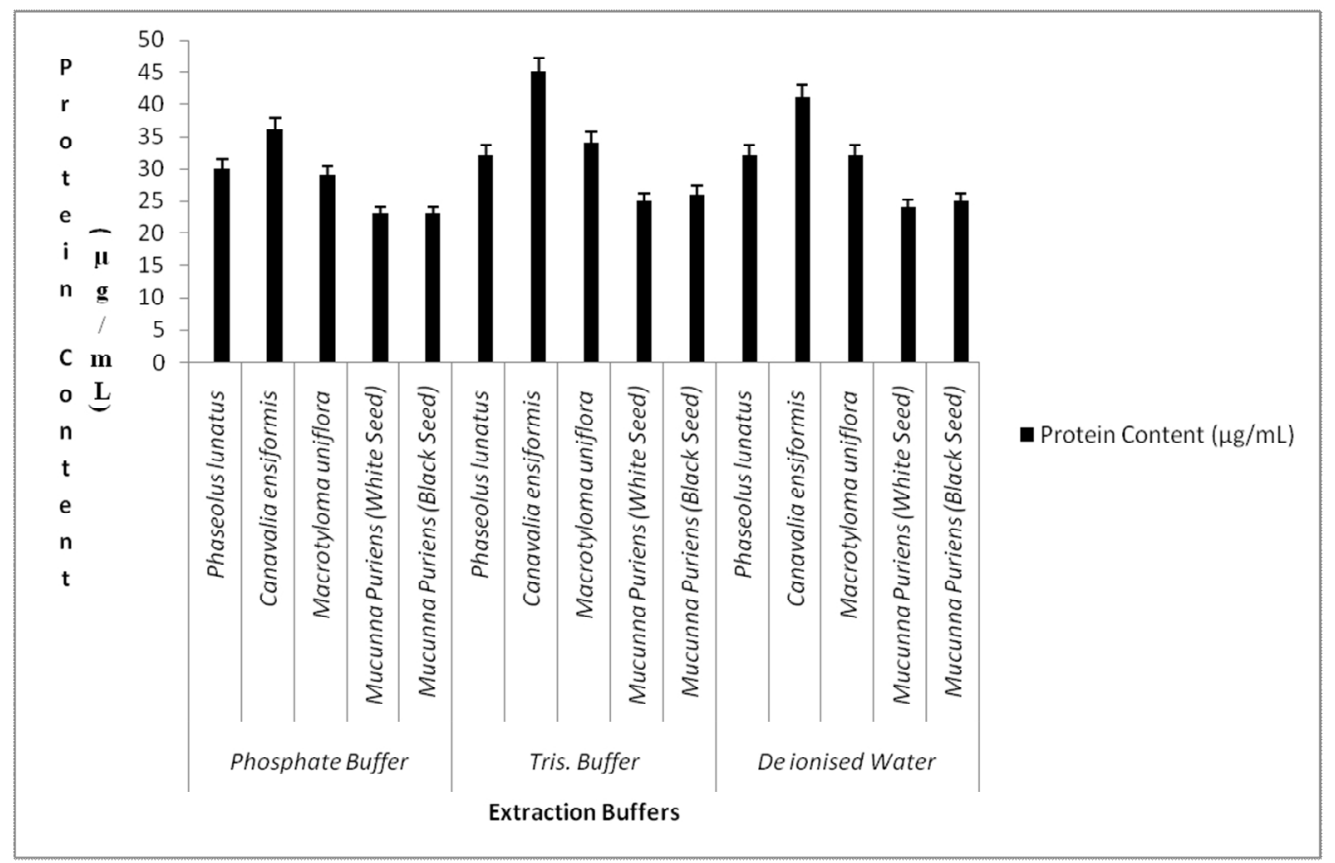

Figure 1: Protein release in buffer solutions and water 

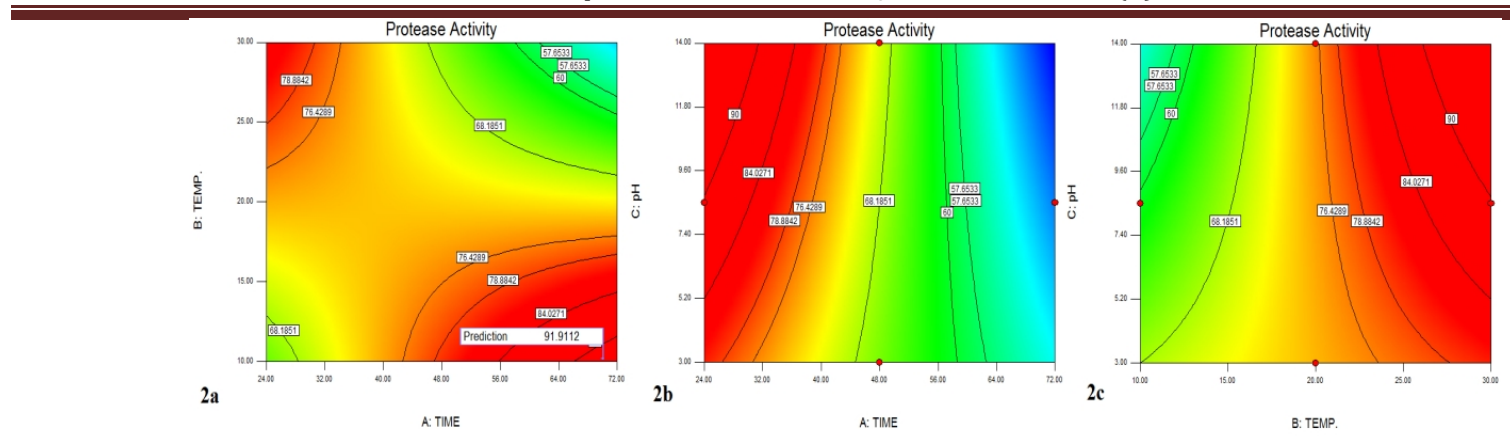

Figure 2: Contour surface plots of optimized extraction parameters. 2a Contour surface plots of influence of Temperature and Time on Protease Activity. 2b Contour surface plots of influence of $\mathrm{pH}$ and Time on Protease Activity. 2c Contour surface plots of influence of Temperature and pH on Protease Activity.
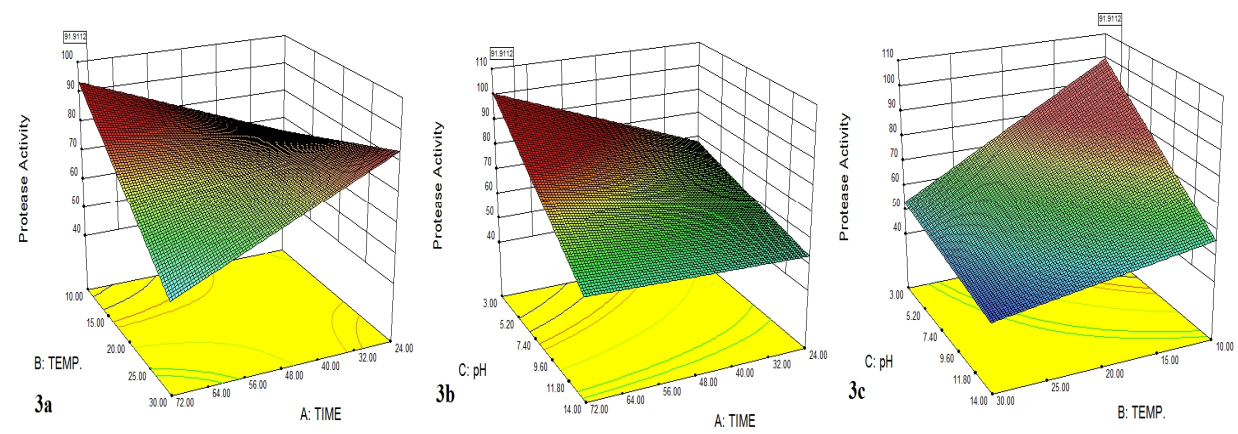

Figure 3: 3 D Surface plots of optimized extraction parameters. 3a Effect of temperature and time on protease activity. 3b Effect of pH and time on protease activity. $3 \mathrm{c}$ Effect of temperature and $\mathrm{pH}$ on protease activity.

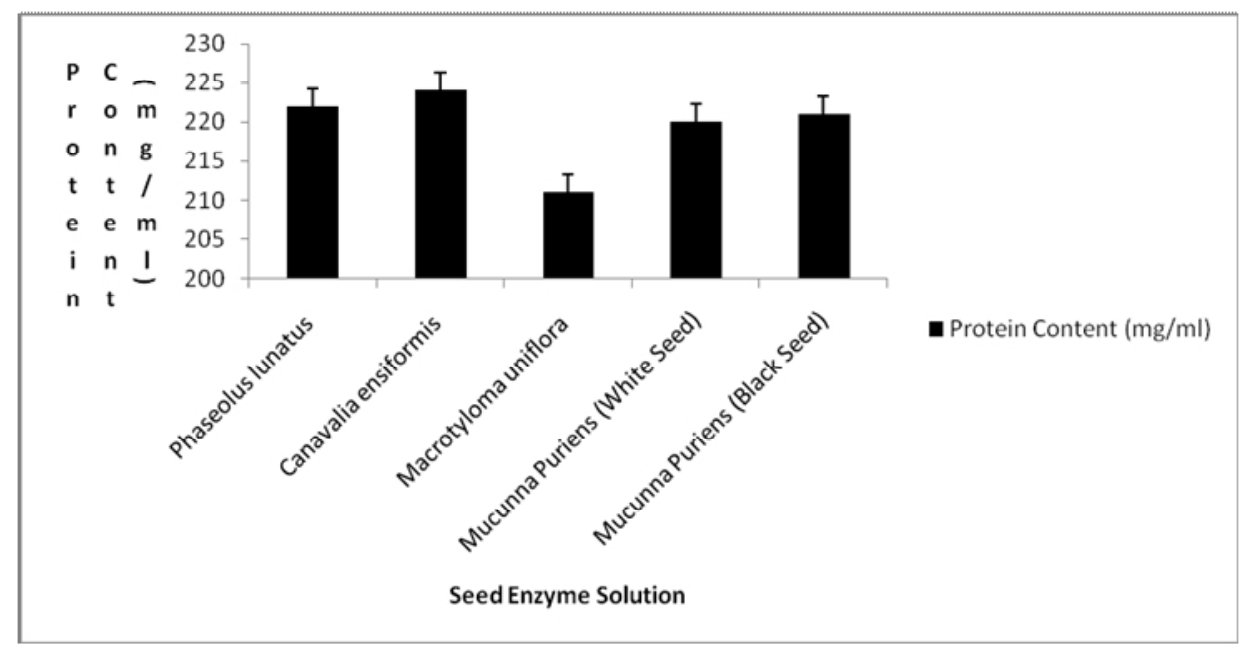

Figure 4: Water soluble protein in crude enzyme solutions of various seeds 


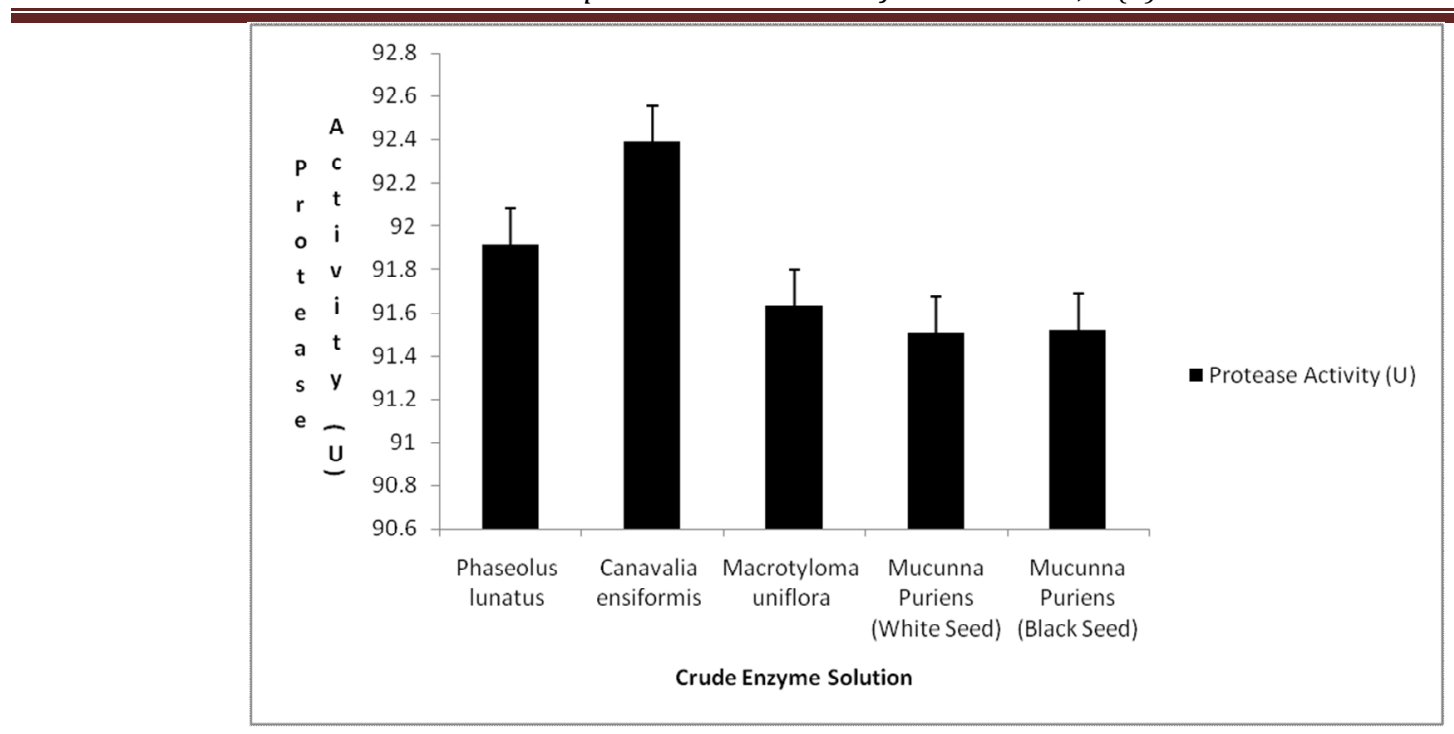

Figure 5: Estimation of protease activity in crude enzyme solutions

\section{CONCLUSION}

From the present study, we conclude that the leguminous seeds under study here are a good alternative to commercial sources of protease enzymes. The abundance of these seeds also plays a role in drastically cutting the cost of enzyme production. The isolation protocol demonstrated in the present study is a very simple, inexpensive method, further reducing production costs. The characterization of the isolated enzyme and their applications are under study. The same protocol may also be applied to examine other seeds as possible enzyme sources.

\section{ACKNOWLEDGEMENT}

We would like to express our gratitude to Mr. Mansh Khare, Dept. of Biotechnology, SRM University for his valuable inputs. We also express our sincere thanks to Prof. Dr. C. Muthamizchelvan, Director (EandT) SRM University for his continued support and encouragement.

\section{REFERENCES}

1. Ashton F. Plant Endopeptidases, In plant Proteolytic Enzymes, Michael J Dalling, Ed., CRC Press, Florida 1976; 1(119): 140

2. Ichishima E. J Ferm Assoc Japan 1964; 22: 393.

3. Yaw Huei Lin and Wen Hsiang Yao. Green Gram Vigna radiate L. Wilczek contains some high proteolytic activities already before germination. Bot Bull Acad Sin 1996; 37: 1-7.

4. Rahman M, Mahberbar L, Arjunmand Bau, Mashiar Rahman M and Fatema Shahjada U. Changes of the enzymes activity during germination of different green gram varieties. Bangladesh J Sci Ind Res 2007; 42(2): 213-216. http://dx.doi.org/10.3329/bjsir.v42i2.474

5. Bau HH, Villanme C, Nicholas JP and Mejean L. Effect of germination on chemical composition, biochemical constituents and anti nutritional factors of soy bean Glycine max seeds. J Sci Food Agric 1997; 73: 1-9. http://dx.doi.org/10.1002/(SICI)1097-0010(199701)73:1<1::AIDJSFA694>3.0.CO;2-B http://dx.doi.org/10.1002/(SICI)10970010(199701)73:1<1::AID-JSFA694>3.3.CO;2-2

6. Fox PF and Morrissey PA. Industrial and Clinical Enzymology. Editors: LJ Vitale, V Simon, Pergamon Press Oxford 1980; 61: 43.

7. Uma Sundaram, Marimuthu M, Anupama V, Gurumoorthi P. Comparative antioxidant quality evaluation of underutilized /less common South Indian legumes. Int J Pharm Bio Sci 2013; 4(2): (B) $117-$ 126.

8. Sumathi, NG Malleshi and Rao SV. Elaboration of amylase activity and changes in past viscosity of some common Indian legumes during germination. Plant Foods Hum Nutr 1995; 47: 341-347. http://dx .doi.org/10.1007/BF01088272 PMid:8577652

9. Preet K and Punia D. Proximate composition, phytic acid, polyphenols and digestibility in vitro of four brown cowpea varieties. Int J Food Sci Nutr 2000; 51: 181-193.

10. Mubarak AE. Nutritional composition and anti nutritional factors of mung bean seeds Phaseolus aureus as affected by some home traditional processes. Food Chem 2005; 89(4): 489-495. http://dx.doi. org/10.1016/j.foodchem.2004.01.007

11. Negi P, Boora and Khetarpaul N. Starch and protein digestibility of newly released moth bean cultivars: Effect of soaking, dehulling, germination and pressure cooking. Nahrung 2001; 45(4): 251-254. http://dx.doi.org/10.1002/1521-3803(20010801)45:4<251::AIDFOOD251>3.0.CO; $2-\mathrm{V}$

12. Lasekan OO. Effect of germination on $\alpha$-amylase activities and rheological properties of sorghum Sorghum bicolor and acha Digitaria exilis grains. J Food Sci Tech 1996; 33(4): 329-331.

13. Muntz K. Proteases and proteolytic cleavage of storage proteins in developing and germinating dicotyledonous seeds. J Exp Botany 1996; 47: 605-622. http://dx.doi.org/10.1093/jxb/47.5.605

14. Kataria A, Chauhan BM and Punia D. Digestibility of proteins and starch in vitro of amphidiploids, black gram X mung bean as affected by domestic processing and cooking. Plant Foods Hum Nutr 1992; 42(2): 117-125. http://dx.doi.org/10.1007/BF02196464 PMid:1374184

15. Akinlosottu A and Akinyele IO. Effect of soaking, dehulling and fermentation on the oligosaccharides and nutrient content of cowpeas Vigna unguiculata. Food Chem 1991; 41: 43-53. http://dx.doi.org /10.1016/0308-8146(91)90130-G

16. Malleshi NG, Daodu MA and Chandrasekar A. Development of weaning food formulations based on malting and roller drying of sorghum and cowpea. Int J Food Sci Tech 1989; 24: 511-519. http:// dx.doi.org/10.1111/j.1365-2621.1989.tb00674.x

17. Helland MH, Wicklund $\mathrm{T}$ and Narvhus JA. Effect of germination time on alpha-amylase production and viscosity of maize porridge. Food Res Int 2002; 35: 315-321. http://dx.doi.org/10.1016/S0963-9969(01)002022

18. Gurumoorthi P and Uma S. Heat-stable and heat-labile anti nutritional profile in Mucuna pruriens var utilis: Effected by germination. Intl Food Res J 2011; 18(4): 1421-1426.

19. Marion M Bradford. A rapid and sensitive method for the quantitation of microgram quantities of protein utilizing the principle of protein-dye binding. Anal Biochem 1976; 76: 248-254.

20. Dahot M Umar. Investigation of protease in plant seeds. J Islamic Acad Sci 1992; 5: 4, 241-244.

21. Tapash Paul, Rubel Mozumdu NHH, Syed MA and Aktaruzzman M. Proximate composition, mineral contents and determination of protease from green gram (Vigna radiate 1. Wilczek). Bangladesh Res Pub J 2011; 5: 207-213.

22. Srimanta Ray. RSM: A statistical tool for process optimization; 2006. http://www.indiantextilejournal.com/articles/FAdetails.asp?id=393Accessed on 15/01/2013.

23. Akhtaruzzaman M, Rubel Mozumder NHM, Ripa Jamal, Atikur Rahman and Tanjina Rahman. Isolation and Characterization Protease Enzyme from Leguminous Seeds. Agri Sci Res J 2012; 2(8): 434-440.

24. Ammonium sulphate calculator; EnCore Biotechnology Limited Gainsville, Florida; 2013. http://www.encorbio.com/protocols/AMSO4.htm - Accessed on 15/01/2013.

25. Lowry $\mathrm{OH}$, Rosenbrough NJ, Farr AL and Randall RJ. Protein Measurement with the Folin reagent. J Biol Chem 1951; 193: 265-275. PMid: 14907713 
26. Kunitz M. Crystalline soybean Trypsin Inhibitor, II. General properties. J Gen Physiol 1947; 30(4): 291-310. http://dx.doi.org/10.1085 /jgp.30.4.291PMid:19873496 PMCid:PMC2142836

27. Alistair Rogers and Yves Gibon. Enzyme Kinetics: Theory and Practice in Schwender J. ed, Plant Metabolic Networks, Springer Science Business Media, LLC; 2009. p. 71-103.

28. Egwim Evans C. Partial characterization of protease activity from Rhynchophorus palmarum Palm Weevil. African J Food Sci Tech 2011; 2(6): 140-145.

29. Kamini NR, Hemachander C, Mala JGS, Puvanakrishnan R. Microbial enzyme technology as an alternative to conventional chemicals in leather industry. Financial Time Information Ltd Asia Intelligence Wire; 2004. PMid:14992693
30. Nadafi MF, Deobagkar D. Potential application of protease isolated from Pseudomonas aeruginosa PD100. Electron J Biotechnol 2005; 8(2): 122-125.

31. Aoki H, Nazmul HMd, Matsno K, Hagiwara T, Watabe S. Partial purification of protease that are generated by processing of the northern shrimp Pandalus borealis and which can tenderize beef. Int J Food Sc. Technol 2004; 39(5): 471-480.

Cite this article as:

Anupama V., Marimuthu M., Uma Sundaram, Gurumoorthi P. Optimization, isolation and partial characterization of proteases from underutilized and common food legumes. Int. Res. J. Pharm. 2013; 4(7):99-106 http://dx.doi.org/10.7897/2230-8407.04722 